\title{
Современная этническая идентичность ойратов и тувинцев Китая: к вопросу о специфике национального вопроса в КНР"
}

\author{
Эльза П. Бакаева \\ Калмыцкий научный центр Российской академии наук, Российская Федерация, \\ Жанна М. Юиа \\ Институт филологии Сибирского отделения Российской академии наук, Российская Федерация
}

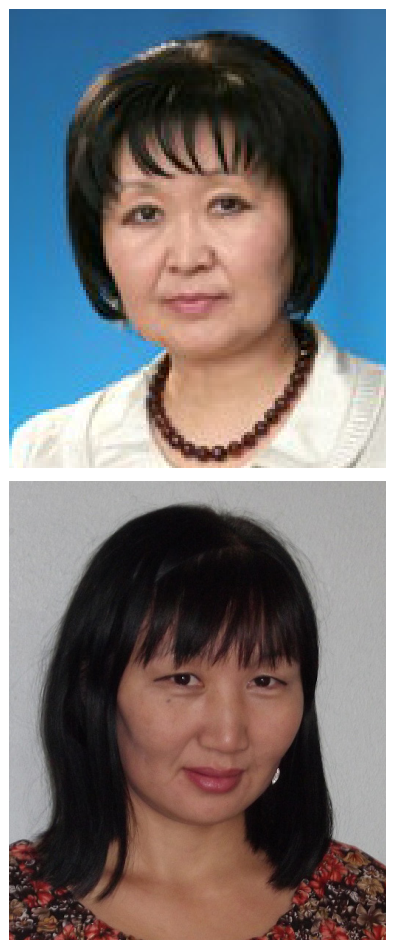

Статья посвящена освещению специфики национального вопроса в Китайской Народной Республике на примере ойратов и тувинцев. Авторы показывают сложный состав монгольских народов Китая, приводят данные по истории их изучения в 1950-е г2., когда в КНР происходил этап становления национальной политики, решались вопросы национально-языкового строительства и реализовывался проект этнической классификации.

Учет состава населения КНР, сложившийся с периода 1956-1976 г2., затронул все стороны жизни китайского общества, в том числе проблему национального состава. В первой половине 1950-х г2. проводились исследования в области этнографии неханьских народов и языков национальных меньшинств КНР. Несмотря на это был принят принцип объединения народов, направленный на реализацию политики их слияния. Ряд монголоязычных народов, а также и тюркоязычные тувинцы были официально включены в понятие «монголы».

Сегодня в КНР проводится иная национальная политика. Но тезис о 56 национальностях КНР продолжает бытовать. Принимая необходимость официальной монгольской идентичности, представители ойратов и тувинцев тем не менее сохраняют свою этническую идентичность.

Ключевые слова: национальный вопрос; КНР; Китай; малочисленные народы Китая; монголы; ойраты КНР; тувинцы Китая; синьцзянские калмыки; тувинцы; этническая идентичность

"Исследование проведено в рамках государственной субсидии - проект «Комплексное исследование процессов общественно-политического и культурного развития народов Юга России» (регистрационный номер АААA-А19-119011490038-5).

\section{Для цитирования:}

Бакаева Э. П., Юша Ж. М. Современная этническая идентичность ойратов и тувинцев Китая: к вопросу о специфике национального вопроса в KHP [Электронный ресурс] // Новые исследования Tyвы. 2019, № 4. URL: https:// nit.tuva.asia/nit/article/view/893 (дата обращения: дд.мм.гг.). DOI: 10.25178/nit.2019.4.15

Бакаева Эльза Петровна - доктор исторических наук, заместитель директора по научной работе Калмыцкого научного центра РАН. Адрес: 358000, Россия, г. Элиста, ул. им. И. К. Илишкина, д. 8. Тел.: +7 (84722) 3-55-15. Эл. адрес: bakaevaep@kigiran.com ORCID ID: 0000-0002-5188-1202

Юша Жанна Монгеевна - доктор филологических наук, ведущий научный сотрудник сектора фольклора народов Сибири Института филологии Сибирского отделения Российской академии наук. Адрес: 630090, Россия, г. Новосибирск, ул. Николаева, д. 8. Тел.: +7 (383) 330-14-52. Эл. адрес: zhanna-yusha@yandex.ru ORCID ID: 0000-0002-4076-4553

Bakaeva Elza Petrovna, Doctor of History, Deputy Director for Research, Kalmyk Scientific Center of the Russian Academy of Sciences. Postal address: 8 Ilishkin St., 358000 Elista, Russian Federation. Tel.: +7 (84722) 3-55-15. E-mail: bakaevaep@kigiran.com Yusha Zhanna Mongeevna, Doctor of Philology, Leading Research Associate, Sector of Folklore of Siberian Peoples, Institute of Philology, Siberian Branch of the Russian Academy of Sciences. Postal address: 8, Nikolaeva St., 630090 Novosibirsk, Russian Federation. Tel.: +7 (383) 330-14-52.E-mail: zhanna-yusha@yandex.ru 


\title{
Contemporary ethnic identities of China's Oirats and Tuvans: specificity of the PRC's national question revisited ${ }^{\circ}$
}

\author{
Elza P. Bakaeva \\ Kalmyk Scientific Center of the Russian Academy of Sciences, Russian Federation, \\ Zhanna M. Yusha \\ Institute of Philology, Siberian Branch of the Russian Academy of Sciences, Russian Federation
}

\begin{abstract}
The article examines some specific features of the national question in the People's Republic of China through the examples of ethnic Oirats and Tuvans. The paper illustrates the complicated structure of China-based Mongolic peoples, provides insights into the history of their explorations during the 1950s when the PRC witnessed the shaping of nationalities policies, nation and language building, implementation of the ethnic classification project.

The structural registeration of the PRC's population established between 1956 and 1976 dealt with all aspects of China's social life, including that of ethnic composition. The early-to-mid 1950s abounded with ethnographic studies of non-Han peoples and investigations of minority languages. Despite all that, authorities chose to introduce the principle of merging peoples as part of unification policies. A number of Mongolic peoples, including the Turkic-speaking Tuvans, started being officially referred to as 'Mongols'.

Nowadays the Chinese government pursues another policy but the idea of '56 nationalities of the PRC' is still there. So, understanding the necessity of official 'Mongolian' identity ethnic Oirats and Tuvans, nonetheless, retain their ethnic identities.
\end{abstract}

Keywords: national question; PRC; China; ethnic minorities of China; Mongols; Oirats of the PRC; Tuvans of China; Xinjiang Kalmyks; Tuvans; ethnic identity

\footnotetext{
" The reported study was funded by government subsidy - project name 'Socio-Political and Cultural Development of South Russia's
} Peoples: a Comprehensive Research of Respective Processes' (registration number AAAA-A19-119011490038-5).

\section{For citaton:}

Bakaeva E. P. and Yusha Zh. M. Contemporary ethnic identities of China's Oirats and Tuvans: specificity of the PRC's national question revisited. The New Research of Tuva. 2019, № 4 [online] Available at: https://nit.tuva.asia/nit/article/ view/893 (access date ...). DOI: 10.25178/nit.2019.4.15

\section{Введение}

Национальный состав Китая - сложная научная проблема, вопросы ее изучения связаны с особенностями переписей населения и отсутствием текущего статистического учета движения населения (Андреев, 2015: Электр. ресурс), а также историческими условиями после образования КНР. В 2000 г. в КНР численность неханьских народов составляла 106430 тыс. чел., или 8,41\% от всего населения страны (Лазарева, 2010: 22). Из официальных 56 национальностей 55 - этнические меньшинства, а 91,59\% составляют ханьцы. Конституция КНР (1982 г.) провозглашает принцип равноправия национальностей ${ }^{1}$. Национальная политика реализуется посредством Закона КНР о районной национальной автономии 1984 г. Согласно «Белой книге» «Национальная политика Китая и общее процветание и развитие всех национальностей», единение национальностей - одна из главных задач государства ${ }^{2}$. Но численность неханьских народов в Китае велика - более 100 млн чел., 44 из 55 нацменьшинств имеют национальные автономные округа с населением $75 \%$ от общего числа этнических меньшинств, и расселены они на 64\% территории страны (Алексеева, 2012: 132). Численность монголов, по данным 2010 г. - 5981,84 тыс. чел. (Ставров, 2013: 148). При этом «в современном Китае споры по поводу понятия “нация” обострились <...> За спорами, которые идут вокруг концептуальных подходов к трактовке нации, стоит вопрос о праве наций на самоопределение» (Ху Янсинь, 2006: 12).

\footnotetext{
${ }^{1}$ Конституция КНР (в редакции 2018 г.) [Электронный ресурс] // World Business Consult. URL: www.wbconsult.ru > files > docs > Constituion_KNR (дата обращения: 31.08.2019).

${ }^{2}$ Белая книга «Национальная политика Китая и общее процветание и развитие всех национальностей» [Электронный ресурс] // Russian.china.org.cn. URL: russian.china.org.cn/government/archive/baipishu/txt/2009-12/14/content_19062289_5.htm (дата обращения: 31.08.2019).
} 
Проблема исследования. Среди факторов недостаточной изученности этнической идентичности меньшинств КНР- особенности демографической ситуации и демографической политики, начальный этап изучения их истории и культуры. Цель статьи - анализ вопросов этнической идентичности ойратов и тувинцев Китая, не выделяемых в качестве отдельных народов и обозначаемых как «монголы», в контексте истории изучения монгольских народов в 1950-е гг., на этапе становления национальной политики и проекта этнической классификации народов Китая. Новизна работы заключается в том, что впервые будут в комплексе проанализированы вопросы идентичности ойратов и тувинцев Китая, обозначаемых в китайской официальной статистике как «монголы», и показаны условия, в которых произошло их объединение в официальной национальной политике и статистике под единым термином.

Источниками для исследования послужили материалы опросов, проводившихся Э. П. Бакаевой у представителей этнических групп ойратов КНР в 2017-2018 гг., а также полевые материалы Ж. М. Юша, собранные среди тувинцев Китая в течение ряда полевых сезонов в 2010-2018 гг. (Юша 2017abcd, 2018), данные, опубликованные в разных работах, посвященных ойратам и тувинцам КНР, в том числе воспоминания руководителя монгольских экспедиций 1954-1956 гг. Б. Х. Тодаевой, в 1960-1980-е гг. опубликовавшей ряд работ о языках монгольских народов КНР (Тодаева, 1960, 1961, 1964, 1973, 1985, 1986), интернет-ресурсы (в том числе фильм «Zuunsh Butssan Baatarmuud» и его обсуждение калмыцкой аудиторией в социальных сетях, отражающие идентичность синьцзянских ойратов).

\section{Ойраты Китая}

В литературе, посвященной национальной политике КНР и вопросам демографии, ученые обычно оперируют данными китайской статистики, опираясь на официальные данные, и в них чаще не отражаются сведения о немногочисленных народов Китая, не входящих в число 55 неханьских народов. Сопоставимыми с самыми малочисленными из меньшинств КНР ${ }^{1}$ являются тувинцы Синьцзян-Уйгурского автономного района (далее - СУАР) - от 2,5 до 6 тыс. чел. (Юша, 2017a: 102-106, Электр. ресурс; Юша, 2018: 14), но их включают в состав монголов, как и ойратов, число которых также различается в источниках. Так, по китайским источникам, ойратов примерно 100 тыс. чел. (Очирова, Бембеев, 2012: 158), а по данным, приведенным в изданном в Гонконге «Лингвистическом атласе Китая», - 139 тыс. чел. (Language atlas of China, 1987, 1989²). Б. Х. Тодаева отмечала в 1950-х гг., что в Синьцзяне ойратов около 65000 человек (Тодаева, 2012: 47). С. К. Хойт пишет о 250 тыс. ойратов в КНР (Хойт, 2008: 150). У. Осорин приводит данные о в целом 260 тыс. ойратов в Китае, 170 тыс. - в СУАР (Осорин, 2010: 6): известно, что ойраты расселены также в Автономном районе Внутренняя Монголия (далее - АРВМ) КНР, (в т. ч. алашаньские хошуты и эдзинейские торгуты) и других провинциях. Есть сведения о численности 70 тыс. чел кукунорских хошутов (Бембеев, Лиджиев, 2014: 121). Уточнение вышеуказанных цифр связано со сложностями, определенными спецификой статистики в КНР.

Ху Яньсинь пишет, что в СУАР КНР проживают 47 народов, из них 13 народов (в т. ч. «монголы») «с давних времен» (Ху Янсинь, 2006: 17) 3 . А для исследователей монгольских народов актуальным является не только выделение среди них ойратов, но и выделение среди ойратов разных этнических общностей, что отражает распространенные представления об идентичности ойратов Синьцзяна. К примеру, С. К. Хойт, приводя сводку о численности ойратов в разных провинциях КНР, перечисляет ойратов, олетов, торгутов, хошутов (Хойт, 2008: 151). В целом ойраты Синьцзяна оставались недостаточно исследованными до последних десятилетий.

Тувинцы Китая оставались неизвестными для науки до середины XX в. Китайские ученые считали их монголами, либо казахами, а их язык до 1950 гг. относили к диалекту казахского языка. Только Г. Шимину во время экспедиции 1956 г., проведенной среди тувинцев, удалось доказать, что их язык диалект тувинского языка, а сами они - тувинцы (Shimin, 2005: 409-503).

В целом в начале 1950-х гг. общее число неханьских национальностей было неясным, об этом докладывали китайские ученые на совещаниях (Москалев, 1981: 12). При этом национальная политика КНР с момента ее образования претерпела трансформации; исследователи выделяют в ее реализации

${ }^{1}$ Лоба - 2,9 тыс. чел., гаошань и хэчжэ - 4,5 тыс. чел. (Лазарева, 2010: 21).

${ }^{2}$ Причем ссылка на это издание дается на сайте энциклопедического каталога языков мира «Ethnologue. An encyclopedic reference work cataloging all of the world's known living languages»: http://www.ethnologue.com/16/show_language/xal/

${ }^{3}$ В 2000 г. численность населения СУАР КНР была 19250 тыс. чел., из них нацменьшинства - 10964 тыс. 900 чел. (59,39\%

общего населения) (Капицын, Яо Ван, 2013: 110). 
несколько этапов (Москалев, 1981: 12-49; 1992, 2001 и др.) ${ }^{1}$, а в определении основных этапов в национальной политике КНР выделяются особые подходы, основанные на особенностях «слияния народов» или «конструировании, т. е. с создании искусственных новых народов» (цит. по: Глинкин, 2018: 81-82).

Монголы как северные соседи ханьцев известны им с ранних времен. Для монгольских народов существовало специальное законодательство («Цааджин бичиг» ..., 1998; Лапин, 2015); в политике цинских властей использовались понятия «Внутренняя Монголия» и «Внешняя Монголия», а территория разгромленного в 1758 г. Джунгарского ханства была названа «новой границей» - «Синьцзян».

Но в XX в. с образованием КНР начались новые процессы, которые отразились и в отношении монгольских народов. В связи с реформами возникла необходимость решения проблем переписи и классификации национальностей Китая: происходило создание национальных автономий, решалась задача представительства разных народов в Всекитайском собрании народных представителей (ВСНП). В связи с этим в два этапа (1950-1960-е гг. и 1980-е гг.) реализовывался национальный проект этнической классификации (миньцзу шибе) (Wang, 2015), который считался необходимым в свете развития наций и культур. Сложность его состояла в том, что во время переписи 1953 г. были зафиксированы более 400 этнических наименований, а для представителей меньшинств в ВСНП выделили только 150 мест (Wang, 2015: 6). «Проект этнической идентификации <...> был собирательным термином для серии экспедиций <..>, в которых этнологи и лингвисты должны были определить <...> этнонациональный состав в стране, чтобы эти различные группы могли быть интегрированы в централизованное, территориально устойчивое государство» (Wang, 2015: 6-7).

Реализация проекта столкнулась с отсутствием сведений о языковой ситуации у многих народов и плохой изученностью большинства языков, нехваткой специалистов, отсутствием опыта работы и т. п. (Москалев, 1981: 49), поэтому к исследованиям были привлечены специалисты из СССР (Москалев, 1981: 76-77; Кочукова, 2016: 59).

Изучался и вопрос о монгольских народах: как подходить к исследованию их идентичности, по каким критериям выделять отдельные народы?

Ко времени реализации национального проекта этнической классификации в КНР имелась автономия монголов - Автономный район Внутренняя Монголия (АРВМ), которая была создана в 1947 г. ранее других автономий. Здесь в 1947-1952 гг. были проведены крупные социально-политические изменения; власть концентрировалась на решении проблем монгольского общества; усиливалась местная власть, а также был получен первый опыт индустриализации неханьского общества (Балдано, 2018: 41).

Уже к 1954 г., до первого ВСНП, 38 групп получили официальное признание. Среди них 11 назывались «общепризнанными меньшинствами» (к ним относились и монголы), которые не нужно было оценивать в проекте этнической идентификации (Wang, 2015: 9). Но наличие автономии монголов и большая территория их расселения не могли не определить включение АРВМ и Синьцзяна в полигоны для изучения вопросов идентичности монгольских народов.

В 1954-1957 гг. учеными Центральной Академией национальных меньшинств (ЦАНМ ${ }^{2}$ ) и Пекинского университета проводилось активное изучение монгольских народностей КНР, были проведены экспедиции по изучению их языков. Советником в Институте языкознания АН КНР и в ЦАНМ тогда был приглашенный в 1954 г. Г. П. Сердюченко. Его супруга Б. Х. Тодаева являлась научным консультантом в ЦАНМ и Пекинском университете по монгольским языкам, где через месяц после их прибытия была создана кафедра монгольского языка. Сотрудниками кафедры стали представители разных монгольских национальностей (в том числе и ойратов), работавшие в комитетах по работе в области национальных языков, созданных при правительстве АРВМ, а также в университете.

Проводившаяся в ЦАНМ работа по изучению монголоязычных народов была определена резолюцией Административного совета Центрального Народного Правительства в области национальноязыкового строительства (Москалев, 1981: 64). Уже в октябре 1954 г. ЦАНМ провела совещание по

${ }^{1}$ До образования КНР (Жоголев, 1991: 8-9; Глинкин, 2018: 83; Лазарева, 2010: 22); 1949-1957 гг.; 1958-1976 гг (Глинкин, 2018: 81); после 1976 г.

${ }^{2}$ Как отмечал Н. Н. Чебоксаров, Центральная академия национальных меньшинств (ЦАНМ) была создана в 1951 г. и называлась «Чжунъян миньцзу сюэюань», что буквально означает «Центральный институт национальностей» (Чебоксаров, 1959: 137). А 23 июня 1958 г. «был официально открыт новый научно-исследовательский Институт национальностей Академии наук КНР с тремя отделами: национального вопроса, истории и этнографии» (там же: 144$)$. 
реформе и созданию письменностей для нацменьшинств Китая, в которой принял участие зам. премьера Китая, председатель правительства АРВМ, председатель комитета по делам национальностей Уланху ${ }^{1}$ (Тодаева, 2012: 12), известный как влиятельный политический деятель, сумевший укрепить власть национальной элиты в АРВМ (Балдано, 2018: 41). В конце 1954 г. в ЦАНМ была обсуждена научная программа по изучению «диалектов языка монголов Внутренней Монголии и языка ойратов СиньцзянУйгурского автономного района» (Тодаева, 2012: 16). С начала 1955 г. ЦАНМ и Институт языкознания АН КНР готовили экспедиции, советскими специалистами в этот период и в последующем читался цикл лекций о классификации и особенностях монгольских языков (там же: 17-21). Перед началом экспедиции в обсуждении вопросов реформы монгольской псьменности и выбора основного диалекта (в том числе как основного вопроса «создания самостоятельного монгольского языка во Внутренней Монголии» (там же: 18)) принимали участие представители АРВМ и работники радиовещания г. Пекина, причем руководитель общества по изучению монгольского языка и письменности АРBM Маниджав подчеркивал, что существуют большие отличия в языке2 ойратов и монголов Внутренней Монголии, а также в языке дагуров, что делает невозможным создание одной письменности для этих народов; представители Центральной радиостанции Пекина также обращали внимание на непонимание между носителями «различных диалектов монгольского языка Внутренней Монголии» (там же: 22).

Всего в 1955-1956 гг. состоялись две лингвистические экспедиции по изучению монгольского населения АРВМ, языков дагуров, хорчинов, чахаров, монгоров, баоаней и дунсян, а также ойратов СУАР. Предполагалось обследование этнических групп эдзинейских (торгутов) и алашаньских (хошутов) ойратов и их языка (там же: 22-72).

В 1955 г. в Пекине состоялись три научные лингвистические конференции, оказавшие влияние на процесс национально-языкового строительства (Москалев, 1981: 68), в том числе 6-16 декабря - первая конференция по языкам национальных меньшинств, где прозвучало принятое решение правительства АРВМ о переходе на письменность на основе кириллицы (Тодаева, 2012: 42). Основной докладчик Фу Маоцзи отмечал, что в АРВМ, СУАР и других автономных округах были созданы органы, занимающиеся исследованием национальных языков, вопросами реформы или усовершенствования письменностей (Москалев, 1981: 70). 22-29 мая 1956 г. состоялась конференция по монгольским языкам КНР с участием представителей АРВМ, СУАР, провинций, где проживали монголы, ойраты, дагуры, монгоры, дунсяне, баоани. Ей предшествовали заседания в ЦАНМ по вопросу о монгольском языке и диалектах, совещание в ЦК по делам национальностей и заседание Комитета партии АРВМ, где обсуждали вопрос о выборе «халхаского», «восточного» или «западного» диалекта для основы письменности (Тодаева, 2012: 48-49). Конференция состоялась с участием представителей Центрального Комитета Коммунистической партии Китая, членов правительства и комитета КПК АРВМ, национальный вопрос и реформа письменности рассматривались во взаимосвязи с развитием регионов в целом, работали секции по языкам монгоров, дунсян и баоаней; решили в АРВМ принять новую письменность на кириллице, отмечалось, что в СУАР с 1950 г. выходит газета «на ойратском языке», используются три письменности - ойратская, старомонгольская и новая (на кириллице) (Тодаева, 2012: 50-51).

В последующем планировались экспедиции к алашаньским и эдзинейским ойратам, к юньнаньским монголам, в ЦАНМ обсуждался план изучения монгольских языков на 12 лет (там же: 69-76), но работа была свернута - она не соответствовала новому курсу правительства, которое готовилось к переходу к «большому скачку», новым преобразованиям, и прежде всего переходу к «народным коммунам» как основе общественного строя и слиянию национальностей.

Работа по изучению языков монгольских народов являлась и частью проекта этнической классификации в КНР. Но завершение ее означало закрытие темы для дальнейшего признания национальных меньшинств, ведь «выборочное применение набора стандартов для выделения народов оставляло достаточное пространство, чтобы контролировать процесс идентификации для политических и / или экономических соображений» (Wang, 2015: 8).

Следует отметить, что Б. Х. Тодаева в период работы выделяла «группы по изучению собственно монгольского языка», а также группы по изучению дунсянского, баоаньского, дагурского, монгорского языков. В то же время она выделяла «собственно монгольский язык (язык монголов АРВМ)», ойратский язык, а также языки баоаньский, дунсянский, монгорский, дагурский (Тодаева, 2012: 82-84). При применении академического подхода результаты изучения монгольских народов должны были быть учтены в проекте этнической классификации.

${ }^{1}$ Другие варианты написания его имени Уланху или Уланьфу.

${ }^{2}$ Называемых диалектами. 
Работа советских специалистов по изучению монгольских народов КНР прервалась в августе 1957 г. В это время развернулась «борьба с местным национализмом» (Чебоксаров, 1959: 145), проявлением которого были названы выступления общественных деятелей национальных меньшинств весной 1957 г. с критикой национальной политики КПК, за чем последовали репрессии в $\mathrm{APBM}^{1}$ и СУАР 2 (Балдано, 2018: 42; Буяров, 2016: 40). В этот период реализовывался курс на создание народных коммун, в рамках которых, по мнению китайских идеологов, новые отношения между разными народами должны были способствовать исчезновению национального вопроса (Рахимов, Тешилов, 1974: 97).

Повышение роли национальных языков в автономных районах и разработка национальных письменностей создавали «предпосылки и для реализации <...> принципа использования национальных языков “в качестве важнейшего средства для осуществления власти органами национального самоуправления”» (Москалев, 1981: 84). Но реформа письменности монголов и ойратов и унификация алфавита с новой письменностью монголов МНР были пресечены уже в начале 1958 г. (там же: 98).

Большинство китайских ученых считают, что язык является главной характеристикой этноса, поэтому выделение языков и диалектов у монгольского населения было связано с вопросами составления перечня народов. ЦАНМ проводил эту работу по заданию и под руководством Комиссии по делам национальностей Постоянного Комитета ВСНП (Чебоксаров, 1959: 138), потому задача проекта этнической классификации состояла в группировке народов и уменьшении их числа (Кочукова, 2016: 62). В результате было принято положение о 56 национальностях в КНР, хотя принято считать, что среди 55 нацменьшинств 15 имеют по два и более языков, среди них «монголы», у которых насчитывают два языка, причем вторым считается «язык качжо монголов, проживающих в пров. Юньнань» (Москалев, 1992: 10), ныне относимый к разновидности языка ицзу (там же: 8-11).

Однако после принятия решения о включении в число официальных народов «монголов», как показано выше, были проведены исследования ряда монгольских языков и определенная работа по изучению их идентичности. О первом свидетельствуют проведение специальной конференции и ряда экспедиций, посвященных монгольским языкам, о втором - выводы о самостоятельности языка ойратов (Тодаева, 2012: 51, 84) и факты включения докладов советских специалистов в программы конференций и совещаний, на которых излагалась позиция о необходимости развития «национальной культуры всех монголоязычных народностей КНР» (там же: 69).

Как показывают исследования, проводимые в последние десятилетия в СУАР КНР, ойраты и тувинцы сохраняют свою этническую идентичность и культуру (Бичеев, 2011; Лиджиев, Бембеев, 2014; Меняев, 2012; Монгуш, 1997, 2010; Намжавин, 2004; Осорин, 2010, 2015; Очирова, Бембеев, 2012; Юша, 2017abc, 2018 и др.).

В КНР ойраты официально именуются монголами. Российские исследователи монгольского населения СУАР обычно называют ойратами, которые представлены торгутами (этническими преемниками калмыков, откочевавших в 1771 г. из России в пределы Китая) и небольшими группами олетов (элютов), дербетов и хошутов, захчинов, алтайских урянхайцев (и относимых к ним кок мончаков), а также чахаров, переселенных в XVIII в. из Внутренней Монголии (Очирова, Бембеев, 2012: 146; Лиджиев, Бембеев, 2014: 79). В калмыковедении торгутов СУАР КНР называют «синьцзянскими калмыками» либо «ойратами (калмыками)», отмечается, что торгутов, олетов, хошутов и дербетов СУАР, как и калмыков России и ряд ойратских групп Западной Монголии, «можно рассматривать как осколки некогда единого ойратского народа; соответственно, их язык <...> считать говорами и диалектами ойратского языка, относящегося к западной ветви монгольских языков» (Лиджиев, Бембеев, 2014: 79)3. В публикациях также используется термин «ойраты Синьцзяна», но отмечается, что их в КНР называют «өөрд моңһл» (ойрат-монголы) или «моңһл» (монголы) (Очирова, Бембеев, 2012: 146).

Ойратоведы отмечают одновременное образование в XV-XVII вв. двух родственных этносов: собственно монголов, или восточных монголов, и ойратов (Санчиров, 2013: 45-46). В энциклопедии «Народы и религии» в статье об ойратах говорится о них как ряде народностей (Народы и религии, 1998: 396), отмечается, что они консолидируются с монголами (там же: 166, 351), а в общей статье о

${ }^{1}$ Ранее, в сентябре 1956 г., на VIII съезде КПК, Уланху выступил с критическиеми замечаниями и «указал также на важнейшие проявления великоханьской идеологии, серьезно мешавшие национальному строительству, в том числе на „игнорирование особенностей национальных меньшинств“» (Москалев, 1981: 79-81).

${ }^{2}$ В Синьцзяне исторические условия в целом были особыми, в этом регионе определенное влияние мог оказать исторический фактор, а также «борьба с местным национализмом» (Поликарпов, 2012: 22, 30; 2010: 178).

${ }^{3}$ При этом статус калмыцкого языка в качестве самостоятельного не подлежит сомнению. 
монголах в одном ряду упоминаются «халха, ойраты и др.» (там же: 350), что может быть понято и как наделение одним статусом монголов и ойратов, хотя В. И. Терентьев считает, что термин «ойрат» относится только к средневековой этноисторической общности, а современное его применение связано с попытками конструирования этничности (Терентьев, 2013: 205). В работах монгольских ученых термин «монголы» (монголчууд) используется как общий при обозначении разных народов: халха-монголчууд, буриад-монголчууд, халимаг-монголчууд, ойрад-монголчууд. В публикациях ученых КНР термин «монгол» употребляется в работах, посвященных разным этническим группам - хотя исследовательский материал обусловливает и употребление термина «ойрат» (см.: Chao Gejin, 2001: 414).

Этнический состав ойратских народов прослеживается в этнонимах, обозначающих этнические группы. При этом торгуты КНР, как и торгуты Монголии и калмыки России, сохраняют память о гимнической песне об их родине (Бакаева, 2010, 2011), есть даже памятник песне ${ }^{1}$ (Бакаева, 2016b: 102). Память об общем с российскими калмыками периоде истории сохраняется в культурном наследии торгутов Синьцзяна, свидетельством чего являются образцы фольклора синьцзянских ойратов (Сhaо Gejin, 2001; Balzhin, 2017; Бичеев, Дамринджав, 2017; Убушиева, Дамринжав, 2019; Буудангийн, 2019; Ван Гао Чао, 2012 и др.); память об исторических деятелях, прежде всего об Убаши-хане (Бакаева, 2016а); а также посещения прибывших в Калмыкию ойратов СУАР КНР реки Волги, являющейся символом территории кочевий предков. Связь двух территорий, двух нутуков ${ }^{2}$, п понятием родины проявляется в идентификации синьцзянских калмыков, ныне проживающих в российской Республике Калмыкия, что ярко прослеживается и в научном и литературном творчестве Утнасун Осорин (Осорин, 2005, 2010, 2015; см. также: Топалова, 2016: 127-128). В интернет-пространстве распространен снятый в Китае многосерийный фильм «Zuunsh Butssan Baatarmuud»» (букв. 'Богатыри, вернувшиеся на восток') котором освещается история откочевки калмыков с Убаши-ханом в 1771 г. ${ }^{5}$; герои идентифицируют себя как потомки кереитов Чингис-хана, откочевавшие из-за распрей между монголами. Фильм, снятый в КНР, отражает идентичность ойратов СУАР как «ойрат-монголов» или «монголов», а вместе с тем, и идентичность торгутов, сохранившуюся в условиях доминирования большего по численности монгольского населения.

Таким образом, в районах расселения сохраняющего свою идентичность ойратского населения в СУАР КНР используется самоназвание «ойрат-монголы» или «монголы» (Очирова, Бембеев, 2012: 157). При этом торгуты, составляющие большинство, помнят о принадлежности к аймакам хана и князей, переселившихся в XVIII в.: потомки «старых» торгутов расселены в Баянгол-Монгольском автономном округе (потомки торгутов улуса Убаши-хана), в Или-Казахском автономном округе и Тарбагатае (потомки торгутов улуса нойона Цебек Дорджи, здесь живут также потомки олетов), в Бортала-Монгольском автономном округе (потомки торгутов нойона Бамбара), кроме того, в округе Алтай и в Тарбагатае расселены потомки «новых торгутов» нойона Шеаренга. В отличие от них, проживающие в Цинхае ойраты-хошуты в большей степени утратили свою хошутскую идентичность, приняв самоназвание деед монгол (Бембеев, Лиджиев, 2014: 126).

\section{Тувинцы Китая}

Тувинцы СУАР КНР компактно расселены в Алтайском аймаке Или-Казахского автономного округа, где они проживают совместно с численно преобладающим казахским населением. Самоназвание тувинцев варьируется: кок мончак, мончак, алдай дывазы, дыва. Численность китайских тувинцев, по их собственным подсчетам, составляет около 2500 чел. Сюда же входят представители родоплеменной группы оорцаг (танды), идентифицирующие себя с монголами. Среди тувинского населения зафиксированы 11 групп (сөөк), которые имеют мелкие подразделения салаа и могут объединяться в одну большую группу: дорт сумун (или мончак) (Юша, 2018: 31).

Историками-тувиноведами определены основные этапы происхождения и формирования тувинского этноса (История Тувы, 2001; Маннай-оол, 2004); считается, что «тувинские племена в XVII - первой

\footnotetext{
${ }^{1}$ В сомоне Булган Монголии.

${ }^{2}$ Нутук - территория кочевья, родное место, родина, родной улус

${ }^{3}$ Фильм снят на ойратском (калмыцком) языке; присутствуют титры на старомонгольской письменности и китайской кисьменности.

${ }^{4}$ https://vk.com/videos34369645?fbclid=IwAR2w7Ic35r6qq4TMdNxEJWk2oxpSXwz-bwVY_-L1CNfCwzw0Iv2W915MwQE\&section=al bum_54141391

${ }^{5}$ Интерес к фильму обусловил публикации в социальных сетях как всех его серий, так и переложений текстов на современное калмыцкое письмо, отражающее характерную ойратскую речь.
} 
половине XVIII в. занимали более обширную территорию, чем современные тувинцы. Хотя основная масса населяла территорию современной Тувы, отдельные родоплеменные группы кочевали южнее до г. Кобдо, а восточнее - до оз. Хубсугул и по северной стороне Саян, включая Алтай и Минусинскую котловину до верховьев рек Урунгу, Черного Иртыша и г. Томска» (Тюркские народы ..., 2008: 28), в это время «тувинские племена, несмотря на значительные перемещения, были безусловно сложившейся этнической общностью, которая имела такие этноопределяющие признаки, как общее самосознание и самоназвание, общая территория, язык, общие черты материальной и духовной культуры» (там же: 28).

В 1757 г., во время разгрома Джунгарского ханства Цинской империей, «тувинцы, кочевавшие южнее “линии монгольских караулов” и получившие наименование “алтайские урянхайцы”, оторвались от основной массы тувинцев и оказались в составе Западной Монголии. Часть этнических тувинцев, обитавших в Баян-Ульгийском и Кобдоском аймаках, переселилась на территорию современного Синьцзян-Уйгурского автономного района Китайской Народной Республики» (Маннай-оол, 2004: 115).

Антрополог Намкамидог отмечает, что в последовавший период (1757-1911 гг.), тувинские и монгольские группы, расселенные на Китайском Алтае, были разделены на 7 хошунов (состоящих из 27 сумонов), сгруппированных на две большие области: Зүүнгар (букв. «Правая рука ${ }^{1} »$; в нее входили 4 хошуна: Тевин бега, Мээрен, Ак-соян, Кара-соян, имевшие 15 сумонов) и Баруунгар (букв. «Левая рука»; куда входили 3 хошуна: Тайбын бээзи, Сарул, Кок-мончак, имевшие 12 сумонов). Из них Кокмончак хошун был тувинским, а остальные - монгольскими (Namkamidog, 2009).

Вопросы этнической идентификации тувинцев кратко рассматривались в работах китайских исследователей на основе опроса жителей трех деревней: Ак-Хавы, Хома, Ханаса (Namkamidog, 2009; Bingsheng, 2011). В них отмечается, что тувинское население Синьцзяна считает себя монголами. Так, в своей работе Намкамидог пишет и о том, что китайские тувинцы не исполняют произведения некогда богатого фольклора, не осталось знатоков сказок, песни не исполняют на родном языке, т. к. молодые тувинцы не владеют родным языком (Namkamidog, 2009: 76). Но это не подтверждается нашими полевыми материалами, собранными на всей территории расселения тувинцев (горно-таежная и горно-степная зоны).

Фольклор китайских тувинцев и ныне является живой и функционирующей системой традиционной культуры, его система жанров демонстрирует единую общетувинскую традицию с этнолокальной спецификой, семантическая наполненность произведений фольклора, а также их прагматика соответствуют идентичным жанрам российских тувинцев (Юша, 2018: 114). Родным языком китайских тувинцев является тувинский - один из зарубежных диалектов современного тувинского языка. Несмотря на малочисленность этноса и отсутствие национальной письменности, язык китайских тувинцев до сих пор выполняет важные задачи: коммуникативную; конструктивную экспрессивную; аккумулятивную, так как на родном языке тувинцы проводят все семейно-бытовые, календарные и похоронно-поминальные обряды (Юша, 2017b). Кроме того, родной язык для тувинцев служит средством этнической идентификации его носителей, а также является одним из главных этнических признаков для выявления традиционной оппозиции «свои/чужие». Однако все же приходится признать, что тувинцы родным языком пользуются исключительно дома или с соплеменниками (там же: 47). Тувинские дети в связи с отсутствием тувинских школ учатся в монгольских или казахских школах с обязательным изучением государственного языка - китайского. Дети, поступающие в монгольскую школу, знают два языка - тувинский и казахский, и по сей день сталкиваются с языковыми проблемами, что свидетельствует о хорошей сохранности родного языка китайских тувинцев.

В настоящее время для большей части тувинского населения характерна моноэтническая идентичность. Информанты образ своего народа оценивают как положительный, у индивидов есть потребность в идентификации со своей этнической группой не только в Китае, но и с тувинцами Монголии и России. В основном, это представители семей, в которых оба родителя являются тувинцами.

Однако в связи с тем, что тувинцы КНР живут в иноэтничной среде и официально с 1958 г. отнесены к монголам, в последние годы у них возникают определенные трудности и путаница с этнической самоидентификацией. Некоторые представители мононациональных тувинских семей относят себя и к тувинцам, и монголам. По мнению таких людей, тувинцы являются представителями монгольских родов. Данный тип идентичности свойственен людям, осознающим свое сходство (ментальное, культурное) и с тувинцами, и с монголами, то есть они обладают компетентностью в двух названных

\footnotetext{
${ }^{1}$ Термины «правая рука», «левая рука» отражают деление по сторонам света.
} 
культурах. По этой же причине в тувинском обществе монгольские средние школы, кафедры монгольского языка и литературы при университетах называют тувинскими школами и тувинскими кафедрами, хотя в пределах Китая окружающие народы воспринимают тувинцев как монголов. Поэтому для посторонних людей тувинцы представляются монголами. При наличии межнациональных браков, по принятой традиции, родовая принадлежность определяется по отцовской линии.

В свою очередь, этническая группа китайских монголов называет тувинцев словосочетанием тувинец-монгол (тыва-моол), с одной стороны, принимая их в качестве монголов, с другой - указывая на их принадлежность к другой народности. Тувинцы Кок-Догая и Тамыкы, живущие в южной части Алтайского аймака Или-Казахской области, также называют себя монголами перед представителями других народностей. Соседствующие народы упрекают их в том, что они, не зная монгольского языка, считают себя монголами.

В наши дни у многих пожилых тувинцев Китая бытуют представления о том, что тувинцы оставлены на территории Синьцзяна с XIII в. в качестве отборных войск Чингис-хана, им была доверена охрана границ его северных владений. Об этих воззрениях китайских тувинцев упоминают и другие исследователи (Монгуш, 1997; Namkamidog, 2009). В этом случае мы наблюдаем попытку «удревнить» историю своего народа, а также придать мифологичность «появлению» тувинцев на территории Синьцзяна. «Идентификация происходит в сравнении, в отталкивании от “соседей”, в выработке общих стереотипов восприятия, причем, именно миф становится основой для интерпретации происходящих социальных событий» (Волкогонова, Татаренко, 2001: 161). Этот пример показывает, что «...нация не может просто “возникнуть”, она должна быть “произведена” посредством разработанной мифологии и идеологии» (там же: 162). В подтверждение этого мнения отметим, что у китайских тувинцев существует своеобразный культ Чингис-хана. В каждой тувинской семье на почетном месте, в сакральной зоне жилища, висят его изображения. В последние годы добавилась и ритуальная сторона этого культа. В 2014 г. представители монгольского населения Синьцзяна соорудили обо 1 Чингис-хана возле города Бейтун Алтайского аймака Или-Казахской области, где стали проводить ежегодно освящение этого ритуального объекта, в котором принимают участие многие тувинцы.

Отметим также, что некоторая часть тувинского населения, ранее жившая в местностях БуурулДогай и Чингил, утратила родной язык, этническую идентичность, ассимилировалась и считает себя

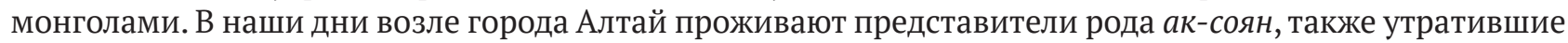
родной язык, идентифицирующие себя монголами.

По нашим наблюдениям, мы можем утверждать, что в переосмыслении этнической принадлежности сказываются историко-культурные связи с монгольскими народами и особенности истории тувинцев Китая.

С одной стороны, тувинский этнос связывают с ойратами и монголами многовековые историкокультурные контакты, добрососедские отношения, схожие условия быта и жизни, проявляющиеся в общности духовной и материальной культуры, народных традиций и обычаев, конфессиональной принадлежности к буддизму, а также использование монгольской письменности и монгольского языка в качестве литературного языка. Имеет значение и то, что для других народов КНР тувинцы воспринимаются монголами, как они записаны в паспортах. По историческим сведениям, казахи-мусульмане Китая, проживающие по соседству с китайскими тувинцами, пришли на Алтай в конце XIX в., поэтому они не имели длительных связей с аборигенным населением. Тувинцы к монголам относятся как к своим собратьям по духу и крови, в отличие от казахов, хотя по языковой принадлежности ближе к последним по тюркской языковой семье.

Для китайских тувинцев в обрядовой сфере важна приверженность другого этноса к шаманизму и буддизму. Об этом свидетельствует то, что тувинцы и казахи, проживая в соседстве, не отмечают вместе ритуалы календарной обрядности, а в семейных обрядах, особенно во время похорон, им категорически запрещено наносить визиты друг к другу.

С другой стороны, в определении современной этнической идентификации большую роль сыграл исторический фактор. На это повлияла сложная судьба тувинского народа, пережившего многие потрясения на протяжении всего XX в. Так, в 1930-е гг. на территории Синьцзяна началась дунгано-казахская война. Из охваченного войной и беспорядками территории Синьцзяна тувинцы бе-

\footnotetext{
${ }^{1}$ Ритуальное сооружение, находящееся на возвышенности или на равнинной местности, которое считается местом поклонения.
} 
жали на Монгольский Алтай, часть из них обосновалась в районе Кобдо и Цэнгэла, где проживали этноплеменные группы тувинцев. Некоторые тувинские семьи через несколько месяцев смогли вернуться обратно на Китайский Алтай, оставив на территории Монголии скот и имущество, спасаясь бегством от монгольских властей. Трагичность ситуации объясняется тем, что в 1930 г. в Монголии также наблюдалась нестабильная политическая ситуация (проводилась коллективизация, велась борьба с богатыми скотоводами-кочевниками, уничтожались буддийские храмы, были репрессированы служители культа). 300 семей вангийн торгутов также переселились в 1930-е гг. из Синьцзяна в Кобдоский аймак Монголии, а в 1944 г. из Китая переселились хобуксарские торгуты, которые расселены ныне в сомоне Булган Кобдоского аймака. Имелись и факты, когда ойраты переселялись в Синьцзян и через некоторое время бежали обратно (Бакаева, 2016d).

По воспоминаниям тувинцев, в то страшное время случалось так, что некоторые семьи из Китайского Алтая бежали в Монголию, а затем убегали обратно в Китайский Алтай. Эти сведения подтверждаются материалами 2005 и 2011 гг., собранными нами у цэнгэльских, дарханских, кобдоских тувинцев Монголии: в некоторых случаях за пересечение установленных границ между Китаем и Монголией беженцев арестовывали и сажали в тюрьму. Поэтому молодое поколение монгольских тувинцев до недавнего времени скрывало, что их родители бежали из Китайского Алтая, так как к потомкам беженцев местное население относилось плохо.

В истории синьцзянского населения есть трагические события, связанные с депортацией. В 1957-1958 гг. борьба с «местным национализмом» охватила Синьцзян. В 1958 г. правительство КНР, посчитав, что часть населения не приняла идей социализма, депортировало их в другие местности. Среди них были и тувинцы Ак-Хабы, Ханаса и Хома; депортация тувинцев продолжалась до 1982 г. и отразилась на их идентичности. Как вспоминают пожилые тувинцы, их переселили на новые места, вынудив оставить скот и отстроенные жилища. Местами нового расселения явились для жителей АкХабы - местность Кызыл-Онгу-Чанагаш, а для жителей Ханаса и Хома - местности Халтан и Чунгур. Здесь из кочевников-тувинцев создали коммуну и заставили заниматься земледелием. В первые годы за работу им не платили, только бесплатно кормили и выдавали необходимую сезонную одежду. От тяжелых условий жизни и быта погибла почти треть тувинского населения, включая детей и стариков. По рассказам очевидцев, в те годы еще распространилась эпидемия оспы.

В 1961 г., не выдержав невыносимых условий проживания и работы, население Ак-Хабы самовольно покинуло места депортации и вернулось в свою деревню. Не успели китайские тувинцы обосноваться на своей родной земле, как в 1963 г. им предъявили новое обвинение. На этот раз их осудили за то, что они якобы хотят сбежать к тувинцам СССР, перейти границу. Последовала новая депортация, они были отосланы в местность Кара-Ой. Вернуться на родные земли им разрешили только в 1982 г., где пришлось обустраиваться с нуля.

Тувинское население, живущее в районе Кок-Догая и Тамыкы, не подверглось депортации, но в те же годы было территориально разобщено, поскольку жить в одной местности тувинским семьям и родоплеменным группам не разрешалось. Страх разоблачения был настолько сильным, что они боялись называться тувинцами, выдавая себя за монголов. По нашим полевым материалам можно отметить, что в последние годы они только начали объединяться, признавать себя тувинцами.

Поэтому в наши дни у пожилых людей, прошедших через многие трудности и тяготы депортации (1958-1982 гг.), при определении своей национальности перед чужими во многих случаях «срабатывает» защитная реакция. Тогда они называют себя монголами.

Проект китайского правительства по национальной идентификации, когда были и идентифицированы 56 этнических групп Китая (Hou, 2014: 97, Электр. ресурс), реализовался, когда тувинцы находились на чужбине. На территории проживания тувинцев опрос ${ }^{1}$ проводился в 1958 г. Тувинцы Ак-Хабы, Ханаса и Хома, составляющие «ядро этноса», по результатам опроса, большинством голосов изъявили желание называть себя не тувинцами, а монголами (Namkamidog, 2009). На основе описанных исторических примеров можем утверждать, что перемена в осознании этнической идентичности у тувинцев произошла в переломные моменты в истории народа как естественная защитная реакция, когда народ оказался на грани жизни и смерти. О тяжелой судьбе своего народа тувинцы говорят: «У нашего малочисленного тувинского народа нет земли, куда бы не отправляли, нет того, чтобы мы не

${ }^{1}$ Согласно критериям проекта этнической классификации, отбор проходил в 5 этапов, в конце «научные» рекомендации представлялись группе, которая принимала решение - считаться ханьцами, отдельным меньшинством или частью существующего меньшинства (Wang, 2015: 8-9). 
видели» (Полевые материалы Ж. М. Юша). Во время полевого сезона 2013 г. в одной из бесед нами было записано следующее воспоминание знатока традиций и обрядов К.-Б.: «Человек по имени Чигшанчап из Хабы раньше такое рассказывал: нельзя говорить “тыва”, нужно говорить “монгол”. Слово “тува” означает беду, поэтому нужно говорить “монгол”. Какого ты рода, если спросят, нельзя говорить “тыва” - он так рассказывал...» (Юша, 2018: 47-48).

Исходя из этого, можно отрицать присутствие измененной этнической идентичности, когда в глазах тувинцев чужой народ обладает высоким статусом, чем свой. Выдержав большие испытания, в последующие периоды для дальнейшей благополучной жизни китайские тувинцы стали выдавать себя за монголов, скрывая истинную этническую принадлежность.

В последние годы среди китайских тувинцев наблюдается консолидация и рост национального самосознания. Кроме главных признаков этнической идентификации, большое значение в этом вопросе сыграла и роль тувинской музыки в мировой культуре, в частности, распространение горлового пения (хоомея) в Китае, исполняемого тувинскими артистами из России. У китайских тувинцев традиция исполнения горлового пения была забыта, но в настоящее время они возобновляют утерянный пласт культуры. Подчеркнем, что в современной жизни китайские тувинцы ощущают себя неразрывной частью единого тувинского этноса, наблюдается попытка реанимировать этноним тыва 图瓦人 в пределах Китая в качестве самоназвания представителей народа.

\section{Заключение}

Исторические условия, сложившиеся в КНР в середине 1950-х гг., определили объединение ряда народов Китая. Противоречия, накопившиеся между центральной властью и местной властью в АРВМ и СУАР, привели к обострению отношений и репрессиям в автономиях. Несмотря на проведенную значительную работу и перспективные планы по изучению языков и самих монгольских народов в АРВМ, СУАР и разных провинциях КНР, политические решения определили резкие изменения в отношении нацменьшинств КНР, в том числе монголоязычных народов и близкого им населения (в частности, ойратов и тувинцев СУАР КНР). В результате официальное признание в 1954 г. «монголов» оставило выбор единственной идентичности для всех монголоязычных народов и тувинцев.

Исторические и этнокультурные связи ойратов и тувинцев определили общность их истории и культуры. В этнической истории ойратов исследователи выделяют влияние как монголоязычных, так и тюркоязычных групп, а среди алтайских урянхайцев выделяют монголоязычные и тюркоязычные группы (Бакаева, 2016с: 95). Тувинцы издавна являлись соседями ойратов: вместе с алтайским урянхайцами с 1755 г. они переселялись в районы Кобдо и Алтая. В 1762 г. в составе цинского Китая был создан Кобдоский округ, в котором были расселены ойраты и тувинцы. В начале XX в. из края был выделен Алтайский округ, впоследствии он отошел к Китаю (Нямдорж, 2006: 83). Так в составе народов, расселенных в Алтайском округе Китая, остались тувинцы. Длительное проживание их в соседстве с ойратами и этнокультурное родство уже в середине XX в. повлияли на включение тувинского населения в состав народов, объединенных под названием «монгол», что является иллюстрацией к выводу Л. Ванг: «меньшинства были классифицированы в соответствии с различными критериями с непредвиденными обстоятельствами» (Wang, 2015: 8).

Отнесение ойратов и тувинцев к монголам, хотя и не учитывает этническую идентификацию, но основано на общности их исторических судеб, а также общих чертах культуры и конфессиональной принадлежности. Тем не менее, этническая идентичность ойратов КНР и тувинцев КНР сохраняется и поныне.

Однако в отношении изучения языков и идентификации монголоязычных народов, как показывают вышеизложенные материалы, была проделана большая работа. Принятие в 1950-х гг. перечня национальностей КНР повлияло как на социальное и культурное развитие ряда национальных меньшинств Китая, так и на их этнологическое изучение, которое следует продолжать.

\section{СПИСОК ЛИТЕРАТУРЫ}

Алексеева, И. Д. (2012) Образование этнических групп Китая // Вестник Бурятского государственного университета. № 8. С. 132-136.

Андреев, Е. (2015) Демографические перспективы Китая. Часть первая. [Электронный ресурс] // Демоскоп Weekly. 6-9 апреля, № 637-638. URL: demoscope.ru/weekly/2015/0637/demoscope637.pdf (дата обращения: 30.08.2019). 
Бакаева, Э. П. (2010) Ойраты и калмыки. Ойрат-калмыки? (к вопросу о самоидентификации и самоназвании этноса) // Проблемы этнической истории и культуры тюрко-монгольских народов / отв. ред. У. Б. Очиров. Элиста : КИГИ РАН. Вып. II. С. 93-110.

Бакаева, Э. П. (2011) «Нутук»: к вопросу о понятии «кочевье» и территории расселения ойратов (на материалах фольклора) // Монголоведение / отв. ред. Н. Г. Очирова. Элиста : КИГИ РАН. Вып. 5. С. 41-52.

Бакаева, Э. П. (2016а) Исторический факт и его интерпретация: Убаши-хан в истории и культуре калмыков и ойратов // Трансграничная культура: очерки сравнительно-сопоставительного исследования традиций западных монголов и калмыков / Э. П. Бакаева, К. В. Орлова, Д. Н. Музраева и др. Элиста : КалмНЦ РАН. 456 с. С. 344-353.

Бакаева, Э. П. (2016b) Родное кочевье и родина в фольклоре ойратов и калмыков // Трансграничная культура: очерки сравнительно-сопоставительного исследования традиций западных монголов и калмыков / Э. П. Бакаева, К. В. Орлова, Д. Н. Музраева и др. Элиста : КалмНЦ РАН. 456 с . С. $97-110$.

Бакаева, Э. П. (2016с) О происхождении алтайских урянхайцев и некоторых других этнических групп // Трансграничная культура: очерки сравнительно-сопоставительного исследования традиций западных монголов и калмыков / Э. П. Бакаева, К. В. Орлова, Д. Н. Музраева и др. Элиста: КалмНЦ РАН. 456 с. С. $91-96$.

Бакаева, Э. П. (2016d) «Когда не было границы»: формирование этнических групп торгутов в Кобдоском аймаке Монголии в период борьбы за признание независимости страны // Проблемы этнической истории и культуры тюрко-монгольских народов / отв. ред. Э. П. Бакаева. Элиста: КалмНЦ РАН. Вып. 4. C. 21-37.

Балдано, М. Н. (2018) Национальная политика Китая в отношении монгольских народов // Наука и образование сегодня. № 12 (35). С. 40-43.

Бембеев, Е. В., Лиджиев, А. Б. (2014) О научной экспедиции к кукунорским хошутам КНР (хроника и предварительные результаты) // Полевые исследования Калмыцкого института гуманитарных исследований РАН. Вып. 2. Монгольские народы: традиционная культура и современные социокультурные процессы / отв. ред. Н. Г. Очирова. Элиста : КИГИ РАН. С. 101-126.

Бичеев, Б. А. (2011) Фонд ойратских рукописей комитета по делам национальностей СУАР КНР // Память мира: историко-документальное наследие буддизма: мат-лы Междунар. науч.-практ. конф., г. Москва, 25-26 нояб. 2010 г. / отв. ред. В. В. Минаев М. : РГГУ. 359 с.С. 240-244.

Бичеев, Б. А., Дамринджав, Б. (2017) Устная версия «Истории Унекер Торликту-хана» / исслед., пер. с монг., коммент. Б. А. Бичеева и Б. Дамринджава. Элиста: КалмНЦ РАН. 314 с.

Буудангийн, М. (2019) О происхождении некоторых топонимов в эпосе «Джангар» // Oriental Studies. № 41(1). С. 78-86. DOI: 10.22162/2619-0990-2019-41-1-78-86

Буяров, Д. В. (2016) Национальная политика Китая в конце 1950-х -конце 1970-х гг. // Историческая и социально-образовательная мысль. Т. 8. №1/1. С. 39-43.

Ван Гао Чао (2012) Традиционная музыкальная культура ойратов. Элиста: Издат. дом «Герел». 263 с.

Волкогонова, О. Д., Татаренко, И. В. (2001) Этническая идентификация русских, или искушение национализмом // Мир России. № 2. С. 149-166.

Глинкин, В. С. (2018) Периодизация национальной политики КНР (1949 г. - начало XXI в.) // Вестник Томского государственного университета. История. № 51. С. 81-84.

Жоголев, Д.А. (1991) Политика Коммунистической партии Китая в районах национальной автономии (80-е годы) : автореф. дис.... канд. ист. наук. М. 14 с.

История Тувы (2001): в 3 тт. / под общ. ред. С. И. Вайнштейна, М. Х. Маннай-оола. Новосибирск : Наука. Т. 1.367 с.

Кочукова, Е. А. (2016) Особенности этнической классификации народов в КНР (по материалам работ Фэй Сяотуна) // Вестник КГУ им. Н. А. Некрасова. № 1. С. 58-63.

Капицын, В. М., Яо Ван (2013) Синьцзян-Уйгурский автономный район Китая: территориальное самоуправление и национальная политика // Ars administrandi. Искусство управления. № 3. С. $107-117$.

Лазарева, Т. В. (2010) Зигзаги национальной политики Китая // Азия и Африка сегодня. № 3. С. 18-25.

Лапин, П. А. (2015) Очерк национального законодательства для монголов в Китае во время династии Цин // Восточный архив. № 1 (31). С. 39-47. 
Лиджиев, А. Б., Бембеев, Е. В. (2014) Заметки о языке ойратов Синьцзяна (по материалам экспедиции 2014 г.) // Полевые исследования Калмыцкого института гуманитарных исследований РАН. Вып. 2. Монгольские народы: традиционная культура и современные социокультурные процессы / отв. ред. Н. Г. Очирова. Элиста : КИГИ РАН. С. 78-86.

Маннай-оол, М. Х. (2004) Тувинцы: Происхождение тувинского народа. Новосибирск : Наука. 164 с.

Меняев, Б. В. (2012) Образцы письменного наследия ойратов, хранящиеся в частных коллекциях Синьцзяна // Вестник Калмыцкого института гуманитарных исследований РАН. № 4. С. 175-180.

Москалев, А. А. (1981) Политика КНР в национально-языковом вопросе (1949-1978). М.: Наука. Гл. ред. вост. лит-ры. 213 с.

Москалев, А. А. (1992) Национально-языковое строительство в КНР (80-е годы). М. : Наука; Гл. ред. вост. лит-ры. 183 с.

Москалев, А. А. (2001) Теоретическая база национальной политики КНР (1949-1999) / отв. ред. В. С. Мясников. М. : Памятники исторической мысли. 222 с.

Монгуш, М. В. (1997) Тувинцы в Китае (историко-этнографический очерк). Кызыл : Изд.- полигр. комплекс «Эне созу». 78 с.

Монгуш, М. В. (2010) Один народ: три судьбы. Тувинцы России, Монголии и Китая в сравнительном контексте. Осака : Национальный музей этнологии. 358 с.

Намжавин, С. (2004) «Ясное письмо» ойратов Синьцзяна КНР : дисс. ... канд. филолог. наук. Элиста. 143 c.

Народы и религии. Энциклопедия (1998) / гл. ред. В. А. Тишков; редколл.: О. Ю. Артемова, С. А. Арутюнов, А. Н. Кожановский и др. М. : Большая Российская Энциклопедия. 928 с.

Нямдорж, Б. (2006) Кобдоский округ в начале XX в. // Эколого-географические, археологические и социоэтнографические исследования в Южной Сибири и Западной Монголии / отв. ред. В. В. Невинский. Барнаул : Изд-во Алт. ун-та. 148 с. С. 80-98.

Осорин, У. (2005) Дееж. Стихи. Элиста : АПП «Джангар». 104 с.

Осорин, У. (2010) Шинжәнә өөрдин шүлгләнә товч хураңһу [Антология поэзии ойратов Синьцзяна] / сост., автор вступ. ст., пер. на совр. калм. яз. Осорин Утнасун. Элиста : КИГИ РАН. 218 с. (На калм. яз.)

Осорин, У. (2015) Шинжәнә өөрднрин болн хальмгудын домг-үлгүрмүд, домгуд, амн үгин туужс: дүңцүллһн болн зергүллһн [Мифы, легенды и предания синьцзянских ойратов и калмыков: сравнительно-сопоставительный анализ]. Элиста : КИГИ РАН. 188 с. (На калм. яз.)

Очирова, Н. Г., Бембеев, Е. В. (2012) Современное демографическое и социально-экономическое положение ойратов Синьцзян-Уйгурского автономного района КНР// Вестник Калмыцкого института гуманитарных исследований РАН. № 4. С. 156-161.

Поликарпов, И.А. (2010) Позиция Советского Союза в отношении национально-освободительного движения в Синьцзяне в 1944-1945 гг. // Известия Алтайского государственного университета. № 4-2 (68). С. 178-181.

Поликарпов, И. А. (2012) Политика Советского Союза в отношении национального движения коренных народов Синьцзяна в 30-40-х гг. ХХ века : автореф. дис. ... канд. ист. наук. Барнаул. 23 с.

Рахимов, Т. Р., Тешилов, Н. А. (1974) Великоханьский шовинизм Пекина в национальном вопросе // Проблемы Дальнего Востока. № 2. С. 90-97.

Санчиров, В. П. (2013) О происхождении основных ойратских этнонимов // Полевые исследования Калмыцкого института гуманитарных исследований РАН. Вып. 1. Ойраты Монголии: история и культура: Сборник статей и полевых материалов / отв. ред. Н. Г. Очирова. Элиста: КИГИ РАН. С.45-58.

Ставров, И. В. (2013) Тенденции демографического развития неханьских национальностей СевероВосточного Китая (начало XXI века) // Вестник Дальневосточного отделения Российской академии наук. № 4 (170). С. 146-151.

Терентьев, В. И. (2013) Ойраты: этнокультурная составляющая политонима контуры современной этноисторической общности // Вестник Томского университета. История. № 3(23). С. 202-205.

Тодаева, Б. Х. (1960) Монгольские языки и диалекты Китая. М. : ИВЛ.138 с. 
Тодаева, Б. Х. (1961) Дунсянский язык. М. : ИВЛ. 152 с.

Тодаева, Б. Х. (1964) Баоаньский язык. М. : Наука. 159 с.

Тодаева, Б. Х. (1973) Монгорский язык. М. : Наука. 392 с.

Тодаева, Б. Х. (1985) Язык монголов Внутренней Монголии. Очерк диалектов. М. : Наука. 130 с.

Тодаева, Б. Х. (1986) Дагурский язык. М. : Наука. 187 с.

Тодаева, Б. Х. (2012) О научной работе в Китайской Народной Республике: дневниковые записи, 1954-1957 гг.: лингвистические экспедиции по изучению языков монгольских народностей Китая. Элиста : КИГИ РАН. 87 с.

Топалова, Д. Ю. (2016) Образ «нутг» в лирике Осорин Утнасн (на примере стихотворения «Нутгтан нерәдсн седкл») // Проблемы этнической истории и культуры тюрко-монгольских народов. Вып. 4 / отв. ред. Э. П. Бакаева. Элиста : КалмНЦ РАН. С. 112-129.

Тюркские народы Восточной Сибири (2008) / отв. ред. Д. А. Функ, Н. А. Алексеев. М. : Наука. 422 с.

Убушиева, Д. В., Дамринжав, Б. (2019) Матримониальные коллизии в калмыцком эпосе «Джангар» и сказаниях тюрко-монгольских народов Сибири // Oriental Studies. № 44 (4). C. 707-715. DOI: 10.22162/2619-0990-2019-44-4-707-715

Ху Яньсинь (2006) Государственная этнонациональная политика в Китае: анализ теоретических подходов и социальных практик в конце XX -начале XXI в. : автореф. дис. ... канд. соц. наук. М. 23 с.

Хойт, С. К. (2008) Последние данные по локализации и численности ойрат // Проблемы этногенеза и этнической истории тюрко-монгольских народов. Вып. 2 / отв. ред. П. М. Кольцов. Элиста : Изд-во КалмГУ. 202с. С. 136-157.

«Цааджин бичиг» («Монгольское уложение»). Цинское законодательство для монголов. 1627-1694 гг. (1998) / Введение, монгольский текст, транслитерация монгольского текста, перевод и комментарии С.Д. Дылыкова. М. : Восточная литература. 341 с.

Чебоксаров, Н. Н. (1959) Основные этапы развития этнографии в Китае // Советская этнография. № 6. С. $123-149$.

Юша, Ж. М. (2017а) Тувинцы Китая в XXI веке: вехи истории и современное состояние [Электронный ресурс] // Новые исследования Тувы. № 1.URL: https://nit.tuva.asia/nit/article/view/699 (дата обращения: 15.07.2019).

Юша, Ж. М. (2017b) Этноязыковая ситуация у тувинцев Китая // Традиционная культура. № 3. С. 46-57.

Юша,Ж.М. (2017c) Фольклорно-этнографические традиции тувинцев Китая (по результатам полевой работы 2016 г.) // Томский журнал лингвистических и антропологических исследований. № 3. С. 90-96.

Юша, Ж. М. (2017d) Фольклор и обряд тувинцев Китая в начале XXI века: структура, семантика, прагматика : дисс. ... доктора филол. наук. Новосибирск. 434 с.

Юша, Ж. М. (2018) Фольклор и обряд тувинцев Китая в начале XXI века. Структура. Семантика. Прагматика. Новосибирск : Наука. 400 с.

Balzhin, D. (2017) Collection and Publication of Oirat Folk Tales of Xinjiang: a Brief Historical Review // Oriental Studies. № 6. C. 138-149.

Bingsheng, G. (2011) 中国 图瓦 演 就 (Zhong guo Tuwa ren yan jiu) [Эволюция и трансформация народа. О китайских тувинцах]. Beijing : s. n. 380 с. (На кит. яз.).

Chao Gejin (2001) The Oirat Epic Cycle of Jangar // Oral Tradition. № 16/2. P. 402-435.

Hou, Y. (2014) The analysis of current situation of Tuva people in China [Электронный ресурс] // Новые исследования Тувы. № 1. URL: https://nit.tuva.asia/nit/article/view/178 (дата обращения:15.07.2019).

Namkamidog (2009) 新疆图瓦人社会文化田野调查与研究 (Xinjiang Tuwaren shenuiwenhua tianyediaocha yu yanjiu) [Полевое исследование общественной культуры синьцзянских тувинцев]. Beijing : s. n. 294 с. (На кит. яз.).

Shimin, G. (2005) Materials on Tuvinian language of China // Алтайские языки и восточная филология : сб. статей / отв. ред. К. Н. Бичелдей и др. М. : Восточная лит-ра РАН. 519 с. С. 409-503.

Wang, L. (2015) The Identification of Minorities in China // Asian-Pacific Law \& Policy Journal. Vol. 16:2. P. $1-21$. 
Language atlas of China $(1987,1989)$ / Gen Ed. (Australia), S. A. Wurm, B. T'sou, D. Bradley; (China) Li Rong, Xiong Zhenghui, Zhang Zhenxing. [In two parts, boxed]. (Pacific Linguistics, Series C, no. 102). 36 maps, 22 sheets text material + addenda et corrigenda. Canberra: Australian Academy of the Humanities and the Chinese Academy of Social Sciences [and] Department of Linguistics, Research School of Pacific Studies, ANU; Hong Kong: Longman Group (Far East). DOI: 10.1017/S0041977X0000598X

Дата поступления: 03.09.2019 г.

\section{REFERENCE}

Alekseeva, I. D. (2012) Obrazovanie etnicheskikh grupp Kitaya [China's national minority education]. The Buryat State University Bulletin, no. 8, pp. 132-136. (In Russ.).

Andreev, E. (2015) Demograficheskie perspektivy Kitaya. Chast' pervaya [China’s demographic prospects]. Demoscope Weekly, April 6-9, no. 637-638 [online] Available at: demoscope.ru/weekly/2015/0637/demoscope637.pdf (access date: 30.08.2019). (In Russ.).

Bakaeva, E. P. (2010) Oiraty i kalmyki. Oirat-kalmyki? (k voprosu o samoidentifikatsii i samonazvanii etnosa) [Oirats and Kalmyks. Oirat-Kalmyks? (The issue of ethnic identity and name revisited)]. In: Problemy ehtnicheskoi istorii i kul'tury tyurko-mongol'skikh narodov [The Turko-Mongols: issues of ethnic history and culture]. Ed. by U. B. Ochirov. Elista, Kalmyk Humanities Research Institute of RAS. Vol. II. Pp. 93-110. (In Russ.).

Bakaeva, Eh. P. (2011) «Nutuk»: k voprosu o ponyatii «kochev'e» i territorii rasseleniya oiratov (na materialakh fol'klora) ['Nutuk': the concept of '(ancestral) pastural lands' and Oirat-inhabited areas revisited (a case study of folklore materials)]. In: Mongolovedenie [Mongolian Studies]. Ed. by N. G. Ochirova. Elista, Kalmyk Humanities Research Institute of RAS. Vol. 5. Pp. 41-52. (In Russ.).

Bakaeva, E. P. (2016a) Istoricheskii fakt i ego interpretatsiya: Ubashi-khan v istorii i kul'ture kalmykov i oiratov [The historical fact and its interpretation: Ubashi Khan in the history and culture of the Kalmyks and Oirats]. In: Transgranichnaya kul'tura: ocherki sravnitel'no-sopostavitel'nogo issledovaniya traditsii zapadnykh mongolov i kalmykov [Cross-border culture: comparative research sketches of Western Mongolian and Kalmyk traditions] / E. P. Bakaeva et al. Elista, Kalmyk Scientific Center of RAS. 456 p. Pp. 344-353. (In Russ.).

Bakaeva, E. P. (2016b) Rodnoe kochev'e i rodina v fol'klore oiratov i kalmykov [Ancestral pastural lands and Motherland in Oirat and Kalmyk folklore]. In: Transgranichnaya kul'tura: ocherki sravnitel'no-sopostavitel'nogo issledovaniya traditsii zapadnykh mongolov $i$ kalmykov [Cross-border culture: comparative research sketches of Western Mongolian and Kalmyk traditions] / E. P. Bakaeva et al. Elista, Kalmyk Scientific Center of RAS. 456 p. Pp. 97-110. (In Russ.).

Bakaeva, E. P. (2016c) O proiskhozhdenii altaiskikh uryankhaitsev i nekotorykh drugikh ehtnicheskikh grupp [The Altai Uriankhai and some other ethnic groups: origins revisited]. In: Transgranichnaya kul'tura: ocherki sravnitel'no-sopostavitel'nogo issledovaniya traditsii zapadnykh mongolov i kalmykov [Cross-border culture: comparative research sketches of Western Mongolian and Kalmyk traditions] / E. P. Bakaeva et al. Elista, Kalmyk Scientific Center of RAS. 456 p. Pp. 91-96. (In Russ.).

Bakaeva, E. P. (2016d) «Kogda ne bylo granitsy»: formirovanie ehtnicheskikh grupp torgutov v Kobdoskom aimake Mongolii v period bor'by za priznanie nezavisimosti strany ['When no frontiers existed': the shaping of ethnic Torghuts in Khovd Province of Mongolia during the nation's independence struggle]. In: Problemy ehtnicheskoi istorii i kul'tury tyurko-mongol'skikh narodov [The Turko-Mongols: issues of ethnic history and culture] / Ed. by E. P. Bakaeva. Elista, Kalmyk Scientific Center of RAS. Vol. 4. Pp. 21-37. (In Russ.).

Baldano, M. N. (2018) Natsional'naya politika Kitaya v otnoshenii mongol'skikh narodov [China's nationalities policy towards Mongolic peoples]. Science and Education Today, no. 12 (35), pp. 40-43. (In Russ.).

Bembeev, E. V. and Lidzhiev, A. B. (2014) O nauchnoi ehkspeditsii k kukunorskim khoshutam KNR (khronika i predvaritel'nye rezul'taty) [About the scientific expedition to China's Kokonur Khoshuts (chronicles and preliminary results)]. In: Polevye issledovaniya Kalmytskogo instituta gumanitarnykh issledovanii RAN [Field studies of the Kalmyk Humanities Research Institute of the RASJ. Vol. 2: 'Mongolic peoples: traditional culture and modern socio-cultural processes'. Ed. by N. G. Ochirova. Elista, Kalmyk Humanities Research Institute of RAS. Pp. 101-126. (In Russ.).

Bicheev, B. A. (2011) Fond oiratskikh rukopisei komiteta po delam natsional'nostei SUAR KNR [Collected Oirat-language manuscripts housed by the XUAR Committee for Nationalities Affairs (PRC)]. In: Pamyat' 
mira: istoriko-dokumental'noe nasledie buddizma [Memory of the world: historical and documental heritage of Buddhism]. Proceedings of the international research and practice conference (Moscow; November 25-26, 2010). Ed. by V. V. Minaev. Moscow, Russian State University for the Humanities. 359 p. Pp. 240-244. (In Russ.).

Bicheev, B. A., and Damrinjav, B. (2017) Ustnaya versiya «Istorii Uneker Torliktu-khana» ['The Story of Uneker Torloqtu Khan': an oral version]. Study, transl., comment. by B. A. Bicheev and B. Damrinjav. Elista, Kalmyk Scientific Cneter of RAS. 314 p. (In Russ.).

Buudangiin, M. (2019) O proiskhozhdenii nekotorykh toponimov v ehpose «Dzhangar» [The Jangar epic: origins of some toponyms revisited]. Oriental Studies, no. 41(1), pp. 78-86. DOI: 10.22162/2619-0990-201941-1-78-86 (In Russ).

Buyarov, D. V. (2016) Natsional'naya politika Kitaya v kontse 1950-kh -kontse 1970-kh gg. [China national policy in the late 1950s to the late 1970s]. Historical and Social Educational Ideas, vol. 8, no. 1/1, pp. 39-43. (In Russ.).

Van Gao Chao (2012) Traditsionnaya muzykal'naya kul'tura oiratov [Traditional musical culture of the Oirats]. Elista, Gerel. 263 p. (In Russ.).

Volkogonova, O. D. and Tatarenko, I. V. (2001) Etnicheskaya identifikatsiya russkikh, ili iskushenie natsionalizmom [Ethnic identity of Russians, or the temptation of nationalism]. Universe of Russia, no 2, pp. 149-166. (In Russ.).

Glinkin, V. S. (2018) Periodizatsiya natsional'noi politiki KNR (1949 g. - nachalo XXI v.) [National policy of the Peoples Republic of China and its periodization]. Tomsk State University Journal. History, no. 51, pp. 81-84. (In Russ.).

Zhogolev, D. A. (1991) Politika Kommunisticheskoi partii Kitaya v raionakh natsional'noi avtonomii (80-e gody) [The Communist Party of China and its policies towards national autonomies (1980s)]. Candidate of History thesis abstract. Moscow. 14 p. (In Russ.).

Istoriya Tuvy [History of Tuva] (2001) : in 3 vols. Ed. by S. I. Vainshtein and M. Kh. Mannai-ool. Novosibirsk, Nauka. Vol. 1. 367 p. (In Russ.).

Kochukova, E. A. (2016) Osobennosti ehtnicheskoi klassifikatsii narodov v KNR (po materialam rabot Fehi Syaotuna) [Peoples of the PRC: peculiarities of ethnic classification revisited (a case study of Fei Xiaotong's works)]. Vestnik of Kostroma State University, no. 1, pp. 58-63. (In Russ.).

Kapitsyn,V.M., YaoVan(2013) Sin'tszyan-Uigurskii avtonomnyi raion Kitaya:territorial'noe samoupravlenie i natsional'naya politika [The Xinjiang Uygur Aytonomous Region of China: territorial self-government and nationalities policies]. Ars administrandi, no. 3, pp. 107-117. (In Russ.).

Lazareva, T. V. (2010) Zigzagi natsional'noi politiki Kitaya [The twists of China's nationalities policy]. Asia and Africa Today, no. 3, pp. 18-25. (In Russ.).

Lapin, P. A. (2015) Ocherk natsional'nogo zakonodatel'stva dlya mongolov v Kitae vo vremya dinastii Tsin [National legislation for Mongols in China in time of Tsyn Dynasty]. Oriental Archive, no. 1 (31), pp. 39-47. (In Russ.).

Lidzhiev, A. B. and Bembeev, E. V. (2014) Zametki o yazyke oiratov Sin'tszyana (po materialam ehkspeditsii 2014 g.) [Notes on the language of Xinjiang Oirats (summarizing the results of the 2014 expedition)]. In: Polevye issledovaniya Kalmytskogo instituta gumanitarnykh issledovanii RAN [Filed studies of the Kalmyk Humanities Research Institute of the RAS]. Vol. 2: 'Mongolic peoples: traditional culture and modern sociocultural processes'. Ed. by N. G. Ochirova. Elista, Kalmyk Humanities Research Institute of RAS. Pp. 78-86. (In Russ.).

Mannai-ool, M. Kh. (2004) Tuvintsy: Proiskhozhdenie tuvinskogo naroda [The Tuvans: origins of the Tuvan people]. Novosibirsk, Nauka. 164 p. (In Russ.).

Menyaev, B.V. (2012) Obraztsy pis'mennogo naslediya oiratov, khranyashchiesya v chastnykh kollektsiyakh Sin'tszyana [Samples of the Oirat written heritage contained in private collections of Xinjiang]. Bulletin of the Kalmyk Institute for Humanities of the RAS, no. 4, pp. 175-180. (In Russ.).

Moskalev, A. A. (1981) Politika KNR v natsional'no-yazykovom voprose (1949-1978) [Policies of the PRC: ethnic and language aspects (1949-1978)]. Moscow, Nauka, GRVL. 213 p. (In Russ.).

Moskalev, A. A. (1992) Natsional'no-yazykovoe stroitel'stvo $v$ KNR (80-e gody) [Nation and language building in the PRC (1980s)]. Moscow, Nauka, GRVL. 183 p. (In Russ.). 
Moskalev, A. A. (2001) Teoreticheskaya baza natsional'noi politiki KNR (1949-1999) [Nationalities policies of the PRC: theoretical basis revisited (1949-1999)]. Ed. by V. S. Myasnikov. Moscow, Pamyatniki Istoricheskoi Mysli. 222 p. (In Russ.).

Mongush, M. V. (1997) Tuvintsy $v$ Kitae (istoriko-ehtnograficheskii ocherk) [Tuvans in China (a historical and ethnographic essay)]. Kyzyl, Ene Sozu. 78 p. (In Russ.).

Mongush, M. V. (2010) Odin narod: tri sud'by. Tuvintsy Rossii, Mongolii i Kitaya v sravnitel'nom kontekste [One nation - three destinies: Tuvans of Russia, Mongolia and China in a comparative perspective]. Osaka, National Museum of Ethnology. 358 p. (In Russ.).

Namzhavin, S. (2004) «Yasnoe pis'mo» oiratov Sin'tszyana KNR [Clear Script of Xinjiang Oirats (PRC)]. Candidate of Philology thesis. Elista. 143 p. (In Russ.).

Narody i religii. Entsiklopediya [Peoples and religions: encyclopedia] (1998). Ed. by V. A. Tishkov et al. Moscow, Bolshaya Rossiiskaya Ehntsiklopediya. 928 p. (In Russ.).

Nyamdorzh, B. (2006) Kobdoskii okrug v nachale XX v. [Khovd District in the early $20^{\text {th }}$ century]. In: Ekologo-geograficheskie, arkheologicheskie $i$ sotsioetnograficheskie issledovaniya v Yuzhnoi Sibiri i Zapadnoi Mongolii [Ecological, geographical, archaeological and socio-ethnographic studies in Southern Siberia and Western Mongolia]. Ed. by V. V. Nevinsky. Barnaul, Altai State University. 148 p. Pp. 80-98. (In Russ.).

Osorin, U. (2005) Deej. Stikhi ['Deeji': poems]. Elista, Dzhangar. 104 p. (In Russ.).

Osorin, U. (2010) Shinjänä öördin shülglänä tovch khuranyu [Poetry of Xinjiang Oirats: anthology]. Comp., introd., interpret. by Osorin Utnasun. Elista, Kalmyk Humanities Research Institute of RAS. 218 p. (In Kalm.).

Osorin, U. (2015) Shinjänä öördnrin boln khal'mgudyn domg-ülgürmüd, domgud, amn ügin tuujs: düntsüllyn boln zergüllyn [Myths, legends and tales of Xinjiang Oirats and Kalmyks: a comparative analysis]. Elista, Kalmyk Humanities Research Institute of RAS. 188 p. (In Kalm.).

Ochirova, N. G. and Bembeev, E. V. (2012) Sovremennoe demograficheskoe i sotsial'no-ekonomicheskoe polozhenie oiratov Sin'tszyan-Uigurskogo avtonomnogo raiona KNR [Oirats of the XUAR (PRC): contemporary demographic and socio-economic conditions]. Bulletin of the Kalmyk Institute for Humanities of the RAS, no. 4, pp. 156-161. (In Russ.).

Polikarpov, I. A. (2010) Pozitsiya Sovetskogo Soyuza v otnoshenii natsional'no-osvoboditel'nogo dvizheniya v Sin'tszyane v 1944-1945 gg. [Position of the Soviet Union according to national-liberal movement in Sinkiang in 1944-1945]. Izvestiya of Altai State University, no. 4-2 (68), pp. 178-181. (In Russ.).

Polikarpov, I. A. (2012) Politika Sovetskogo Soyuza $v$ otnoshenii natsional'nogo dvizheniya korennykh narodov Sin'tszyana v 30-40-kh gg. XX veka [Policies of the Soviet Union towards the national movement of Xinjiang's native peoples in the 1930s-1940s]. Candidate of History thesis abstract. Barnaul. 23 p. (In Russ.).

Rakhimov, T. R., Teshilov, N. A. (1974) Velikokhan'skii shovinizm Pekina v natsional'nom voprose [Beijing's 'great-khanic' chauvinism in ethnic issues]. Far Eastern Affairs, no. 2, pp. 90-97. (In Russ.).

Sanchirov, V. P. (2013) O proiskhozhdenii osnovnykh oiratskikh etnonimov [Origins of the main Oirat ethnonyms revisited]. In: Polevye issledovaniya Kalmytskogo instituta gumanitarnykh issledovanii RAN [Field studies of the Kalmyk Humanities Research Institute of the RASJ. Vol. 1: 'Oirats of Mongolia: history and culture'. Collected articles and field materials. Ed. by N. G. Ochirova. Elista, Kalmyk Humanities Research Institute of the RAS. Pp. 45-58. (In Russ.).

Stavrov, I. V. (2013) Tendentsii demograficheskogo razvitiya nekhan'skikh natsional'nostei SeveroVostochnogo Kitaya (nachalo XXI veka) [The main tendencies of non-Han nationalities demographic development in the North-East China (the beginning of XXI century)]. Vestnik of the Far East Branch of the Russian Academy of Sciences, no. 4 (170), pp. 146-151. (In Russ.).

Terentiev, V. I. (2013) Oiraty: ehtnokul'turnaya sostavlyayushchaya politonima kontury sovremennoi etnoistoricheskoi obshchnosti [Oirats: revisiting ethno-cultural components of the politonym and shapes of the contemporary ethno-historical community]. Tomsk State University Journal. History, no. 3 (23), pp. 202-205. (In Russ.).

Todaeva, B. Kh. (1960) Mongol'skie yazyki i dialekty Kitaya [Mongolic languages and dialects of China]. Moscow, IVL. 138 p. (In Russ.).

Todaeva, B. Kh. (1961) Dunsyanskii yazyk [The Donxiang language]. Moscow, IVL. 152 p. (In Russ.).

Todaeva, B. Kh. (1964) Baoan'skii yazyk [The Bonan language]. Moscow, Nauka. 159 p. (In Russ.). 
Todaeva, B. Kh. (1973) Mongorskii yazyk [The Monguor language]. Moscow, Nauka. 392 p. (In Russ.).

Todaeva, B. Kh. (1985) Yazyk mongolov Vnutrennei Mongolii. Ocherk dialektov [The Mongolian language of Inner Mongolia. An overview of dialects]. Moscow, Nauka. 130 p. (In Russ.).

Todaeva, B. Kh. (1986) Dagurskii yazyk [The Daur language]. Moscow, Nauka. 187 p. (In Russ.).

Todaeva, B. Kh. (2012) O nauchnoi rabote v Kitaiskoi Narodnoi Respublike: dnevnikovye zapisi, 1954-1957 gg.: lingvisticheskie ehkspeditsii po izucheniyu yazykov mongol'skikh narodnostei Kitaya [Chronicles of (my) research work in the PRC: diary notes of 1954-1957, linguistic expeditions aiming to investigate Mongolic languages of China]. Elista, Kalmyk Humanities Research Institute of RAS. 87 p. (In Russ.).

Topalova, D. Yu. (2016) Obraz «nutg» v lirike Osorin Utnasn (na primere stikhotvoreniya «Nutgtan nerädsn sedkl») [The image of 'nutug' in Osorin Utnasn's lyrics (a case study of the poem 'Nutgtan nerädsn sedkl')]. In: Problemy etnicheskoi istorii i kul'tury tyurko-mongol'skikh narodov [The Turko-Mongols: issues of ethnic history and culture]. Ed. by E. P. Bakaeva. Elista, Kalmyk Scientific Center of RAS. Vol. 4. Pp. 112-129. (In Russ.).

Tyurkskie narody Vostochnoi Sibiri [Turkic peoples of Eastern Siberia] (2008). Ed. by D. A. Funk and N. A. Alekseev. Moscow, Nauka. 422 p. (In Russ.).

Ubushieva, D. V., and Damrinjav, B. (2019) Matrimonial'nye kollizii v kalmytskom ehpose «Dzhangar» i skazaniyakh tyurko-mongol'skikh narodov Sibiri [Matrimonial collisions in the Klmyk epic of Jangar and legends of Siberia's Turko-Mongols]. Oriental Studies, no. 44 (4), pp. 707-715. (In Russ.). DOI: 10.22162/26190990-2019-44-4-707-715

Hu Yanxing (2006) Gosudarstvennaya etnonatsional'naya politika v Kitae: analiz teoreticheskikh podkhodov $i$ sotsial'nykh praktik $v$ kontse XX - nachale XXI v. [State ethno-national policies in China: analysis of theoretical approaches and social practices in the late $20^{\text {th }}$ and early $21^{\text {st }}$ centuries]. Candidate of Social Sciences thesis abstract. Moscow. 23 p. (In Russ.).

Khoit, S. K. (2008) Poslednie dannye po lokalizatsii i chislennosti oirat [Latest data on whereabouts and numbers of Oirats]. In: Problemy etnogeneza i etnicheskoi istorii tyurko-mongol'skikh narodov [The TurkoMongols: issues of Ethnogenesis and ethnic history]. Ed. by P. M. Koltsov. Elista, Kalmyk State University. Vol. 2. 202 p. Pp. 136-157. (In Russ.).

«Tsaadzhin bichig» («Mongol'skoe ulozhenie»). Tsinskoe zakonodatel'stvo dlya mongolov. 1627-1694 gg. ['The Code of Mongols': Qing legislation for the Mongols, 1627-1694] (1998). Introd., Mong. text, transliter., transl. and comment. by S. D. Dylykov. Moscow, Vostochnaya Literatura. 341 p. (In Russ.).

Cheboksarov, N. N. (1959) Osnovnye etapy razvitiya etnografii v Kitae [Ethnography in China: key stages of development revisited]. Sovetskaya etnografiya, no. 6, pp. 123-149. (In Russ.).

Yusha, Zh. M. (2017a) Tuvintsy Kitaya v XXI veke: vekhi istorii i sovremennoe sostoyanie [Tuvans in $21^{\text {st }}$ century China: history and contemporary situation]. The New Research of Tuva, no. 1, pp. 101-119. (In Russ.). [online] Available at: https://nit.tuva.asia/nit/article/view/699 (access date: 15.07.2019). (In Russ.) DOI: 10.25178/nit.2017.1.7

Yusha, Zh. M. (2017b) Etnoyazykovaya situatsiya u tuvintsev Kitaya [Ethno-linguistic situation for Tuvans of China]. Traditional Culture, no. 3, pp. 46-57. (In Russ.).

Yusha, Zh. M. (2017c) Fol'klorno-etnograficheskie traditsii tuvintsev Kitaya (po rezul'tatam polevoi raboty 2016 g.) [Folklore and ethnographic traditions of Tuvans of China (based on 2016 fieldwork)]. Tomsk Journal of Linguistics and Anthropology, no. 3, pp. 90-96. (In Russ.).

Yusha, Zh. M. (2017d) Fol'klor i obryad tuvintsev Kitaya v nachale XXI veka: struktura, semantika, pragmatika [Folklore and ritual of China's Tuvans in the early $21^{\text {st }}$ century: sctructure, semantics, pragmatics]. Doctor of Philology thesis. Novosibirsk. 434 p. (In Russ.).

Yusha, Zh. M. (2018) Fol'klor i obryad tuvintsev Kitaya v nachale XXI veka. Struktura. Semantika. Pragmatika [Folklore and ritual of China's Tuvans in the early $21^{\text {st }}$ century: sctructure, semantics, pragmatics]. Novosibirsk, Nauka. 400 p. (In Russ.).

Balzhin, D. (2017) Collection and publication of Oirat folk tales of Xinjiang: a brief historical review. Oriental Studies, no. 6, pp. 138-149. (In Eng.).

Bingsheng, G. (2011) 中国 图瓦 演 就 (Zhong guo Tuwa ren yan jiu) [Evolution and transformation of one ethnos: China's Tuvans revisited]. Beijing. 380 p. (In Chin.).

Chao Gejin (2001) The Oirat epic cycle of Jangar. Oral Tradition, no. 16/2, pp. 402-435. 
Hou, Y. (2014) The analysis of current situation of Tuva people in China. The New Research of Tuva, no. 1 [online] Available at: https://nit.tuva.asia/nit/article/view/178 (access date: 15.07.2019).

Namkamidog (2009) 新疆图瓦人社会文化田野调查与研究 (Xinjiang Tuwaren shenuiwenhua tianyediaocha yu yanjiu) [Social culture of Xinjiang Tuvans: a field study]. Beijing. 294 p. (In Chin.).

Shimin, G. (2005) Materials on Tuvinian language of China. In: Altaiskie yazyki i vostochnaya filologiya [Altaic languages and Oriental philology]. Coll. articles. Ed. by K. N. Bicheldey et al. Moscow, Vostochnaya Literatura. 519 p. Pp. 409-503.

Wang, L. (2015) The identification of minorities in China. Asian-Pacific Law \& Policy Journal, vol. 16:2, pp. 1-21.

Language atlas of China (1987, 1989). Ed. by (Australia) S. A. Wurm, B. T'sou, D. Bradley; (China) Li Rong, Xiong Zhenghui, Zhang Zhenxing. [In two parts, boxed]. (Pacific Linguistics, Series C, no. 102). 36 maps, 22 sheets text material + addenda et corrigenda. Canberra: Australian Academy of the Humanities and the Chinese Academy of Social Sciences [and] Department of Linguistics, Research School of Pacific Studies, ANU; Hong Kong: Longman Group (Far East). DOI: 10.1017/S0041977X0000598X

Submission date: 03.09.2019. 